\title{
$\mathrm{Cs}$ 型 12 モリブドリン酸における Li イオンの 電気化学的インターカレーション特性
}

\author{
Bustam M. AZUMI, 石原 達已*, 西口 宏泰, 滝田 祐作 \\ 大分大学工学部応用化学工学科（干870-1192 大分市旦野原 700)

\section{Electrochemical Intercalation of Li into Heteropoly 12 Molybdophosphoric Acid Ion-exchanged with Cs}

\author{
Bustam M. AZUMI, Tatsumi ISHIHARA, ${ }^{*}$ Hiroyasu NISHIGUCHI, and Yusaku TAKITA
}

\begin{abstract}
Department of Applied Chemistry, Faculty of Engineering Oita University (Dannoharu 700, Oita 870-1192, Japan)
\end{abstract}
Received May 2, 2002 ; Accepted August 9, 2002

\begin{abstract}
Electrochemical $\mathrm{Li}$ intercalation properties in 12-molybdophosphoric and 12-tangstophosphoric acids were investigated. It was found that both 12-molybdophosphoric and 12-tangstophosphoric acids exhibit fairly large capacity for the $\mathrm{Li}$ intercalation. Flat potential of 12-tangstophosphoric acids was $0.5 \mathrm{~V}$, which could be used for the anode of $\mathrm{Li}$ ion battery. 12-molybdophosphoric acid exhibits the flat potential of $1.5 \mathrm{~V}$, although cycle stability is not high. XRD measurement shows the formation of $\mathrm{Li}_{2} \mathrm{MoO}_{4}$ after the intercalation of $\mathrm{Li}$. Therefore electrochemical $\mathrm{Li}$ intercalation occurs by redox between $\mathrm{Mo}^{6+}$ and $\mathrm{Mo}^{4+}$ and so the theoretical $\mathrm{Li}$ intercalation capacity in 12-molybdophosphoric acid is 373 $\mathrm{mAh} / \mathrm{g}$. Ion-exchanging $\mathrm{H}^{+}$in 12-molybdophosphoric acid to $\mathrm{Cs}^{+}$is effective to improve the cycle stability and capacity of $c a .200 \mathrm{mAh} / \mathrm{g}$ is sustained after 10 cycles. De-intercalation potential of $4.0 \mathrm{~V}$ is newly appeared by substitution of Mo in 12-molybdophosphoric acid with $\mathrm{V}$ although the capacity is still not large. Therefore, substitution of $\mathrm{V}$ is effective for increasing the $\mathrm{Li}$ intercalation potential.
\end{abstract}

Key Words : Electrochemical Li Intercalation, 12-Molybdophosphoric Acid, 12-Tangstophosphoric Acid, Cathode, Li Ion Rechargeable Battery, Cs Ion Exchange

\section{1 諸 言}

リチウムイオン二次電池はエネルギー密度が高く, 携帯機 器の電源として広く使われている. 現在の $\mathrm{Li}$ イオン 2 次電 池には正極活物質として $\mathrm{LiCoO}_{2}$ が用いられ，負極には炭素 が用いられている. $\mathrm{LiCoO}_{2}$ は繰り返し特性に優れ, $4.2 \mathrm{~V}$ という高い放電電位を有するものの, Co が高価で資源的な 制約があるので, $\mathrm{LiCoO}_{2}$ に代わる, 安価で高容量な正極材 料の開発は重要な課題となっている ${ }^{1)} . \mathrm{LiNiO}_{2}{ }^{2-3)}$, $\mathrm{LiMn}_{2} \mathrm{O}_{4}{ }^{4)}, \mathrm{LiFePO}_{4}{ }^{5)}$ などが代替可能な正極活物質として 検討されている. 現在，このような正極活物質の検討では， 単純な酸化物からリン酸塩や硫酸塩などへ検討が展開されて いる1-6).このような複合化合物のなかで，現在までに， Mo 系の複合酸化物については検討が殆ど行われておらず, Mo 系化合物の Li イオンの電気化学的な挿入挙動の検討が 望まれる. Mo 系化合物への Liイオンの電気化学的な㨂入 挙動としては $\mathrm{Mo}_{\mathrm{y}} \mathrm{Sn}_{\mathrm{x}} \mathrm{O}_{2}$ への $\mathrm{Li}$ の挿入が検討されており, Mo を添加することで $\mathrm{S}$ 系負極の繰り返し特性が向上する ことが Martos 等により報告されている7). 一方，ゾルゲル 法で合成した $\mathrm{MoO}_{3} の \mathrm{Li}$ 電気化学的な特性も報告されてい

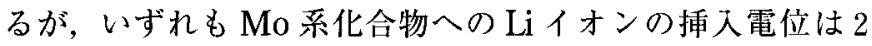
$\mathrm{V}$ 程度である7-9). 一方, $\left(\mathrm{MoO}_{2}\right)_{2} \mathrm{P}_{2} \mathrm{O}_{7}$ などのリン酸塩に ついても検討が行われており，電位は低いながらも比較的大
きな $\mathrm{Li}$ の挿入容量を示すことが報告された ${ }^{10)}$ ・リン酸モリ ブデンは Liの電気化学的な特異な挿入挙動が期待されるに もかかわらず，現在までに，モリブデン系リン酸壏について は Li の電気化学的な挿入特性はほとんど検討が行われてい ない.

へテロポリ酸とは，無機酸が縮合してできるポリ酸を指 し，2種以上の金属によって構成されている化合物である. 代表的な化合物として，12 モリブドリン酸 $\left(\mathrm{H}_{3} \mathrm{PMo}_{12} \mathrm{O}_{40}\right)$ がある.この 12 モリブドリン酸は Fig. 1 に示すように 12 個 の $\mathrm{MoO}_{3}$ からなる八面体が中心の $\mathrm{P}$ の周りを取り囲んだ構 造をしており，8個の非架橋元素の中心にリン $\left(\mathrm{P}^{5+}\right)$ が入 る構造である. 12 モリブドリン酸では Moの一部へへテロ 原子とよばれる異種の原子の導入が可能であり，多様な元素 の添加が可能であることが知られている11-12). また 12 モリ

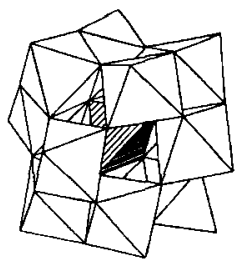

Fig. 1 Structure of 12-Molybdophosporic acid. 
ブドリン酸は電荷のバランスから分子中にイオン交換可能な サイトが3つあり，また中心金属として Fe，Coや Mnな どの置換も可能である ${ }^{111}$ 。一方，1分子中には 12 個の Mo が含まれているので，これらの Mo 原子が全て酸化還元する と極めて高容量な正極活物質になることが期待される.しか し，現在までに 12 モリブドリン酸の Li インターカレーショ ン特性については報告がない，そこで，本研究ではこのよう な縮合へテロポリ酸に扔ける Li の電気化学的なインターカ レーション特性を検討した。

\section{2 実験方法}

用いたイオン交換ヘテロポリ酸は，市販されている 12 モ リブドリン酸（和光純薬）を用いて，金属硝酸塩で，イオン 交換して得た. 12 タングストリン酸は日本新金属製の市販 品をそのまま用いた．イオン交換は飽和溶液を用いて $353 \mathrm{~K}$ で行った，イオン交換を行った後, 試料は遠心分離, 万過 し，573 623 K で酸素ガス気流中に扔いて 15 時間焼成した。 また, $\mathrm{Cs}_{3} \mathrm{PXMo}_{11} \mathrm{O}_{40}(\mathrm{X}=\mathrm{Nb}, \mathrm{W}, \mathrm{V})$ の合成はりン酸, $\mathrm{MoO}_{3}, \mathrm{Nb}_{2} \mathrm{O}_{3}, \mathrm{WO}_{3}, \mathrm{~V}_{2} \mathrm{O}_{5}$ をイオン交換水に溶解した後 $80^{\circ} \mathrm{C}$ の温度で 3 時間混合した。 その後 $85^{\circ} \mathrm{C}$ で乾燥した。得 られた粉末と $\mathrm{Cs}_{2} \mathrm{NO}_{3}$ を所定量秤量し，水溶液中で摚找する ことで, $\mathrm{Cs}^{+}$型へのイオン交換を行った。イオン交換した後 の試料は，遠心分離した，得られた粉体は $300^{\circ} \mathrm{C}$ で酸素気流 中, 15 時間焼成した．結晶構造は $\mathrm{Cu} \mathrm{K} \alpha$ 線を用いる粉末 X 線回折法（XRD,リガク製, Rint 2500）により検討した. 得られた試料の化学組成は誘導結合プラズマ発光分析 (ICP, Perkin Elmer Optima 3000）及び蛍光 X 線分析（島津製作 所，XRF 1800 型）を用いて決定した.

電気化学的 Li のインターカレーション特性は合成した試 料にアセチレンブラック及びポリ 4 フッ化エチレンを 6 ： 3:1の重量比で混合し, ステンレスメッシユに压着して試 験電極とした．電解液として $1 \mathrm{M} \mathrm{LiPF}_{6} / \mathrm{EC}: \mathrm{DMC}(1: 2)$ (宇部興産製) を用い，対極として $\mathrm{Li}$ 金属（厚さ $1 \mathrm{~mm}$ ）を 用いて, 報告に従い半開放型のセルを組み立てた ${ }^{13)}$ 。 セパレ 一タとしてはポリプロピレン (PP) を用いた。充放電測定 は直流定電源（ナガノ BTS-2004 W 型）を用いて試料に 0.4 $\mathrm{mA} / \mathrm{cm}^{2}$ の直流定電流を印加し，5～1 V の電位範囲で測定 を行った。またサイクリックボルタモメトリー測定は同じ電 位範囲で 3 極式セルを用いて $10 \mathrm{mV} / \mathrm{min}$ の掃引速度で測定 した．測定にはソーラトロン製ガルバノスタット/ポテンシ
ヨスタットSI 1287 を用い，計測ソフトとしてCorr Ware 2.0 を用いた。

\section{3. 結果及び考察}

\section{1 種々のヘテロポリ酸の電気化学的 $\mathrm{Li}$ インターカレー} ション特性

Table 1 には本研究で検討したプロトン $\left(\mathrm{H}^{+}\right)$をイオン 交換した $\mathrm{H}^{+}$型へテロポリ 12 モリブデート及び 12 タングス テートの正極特性を示した. XRD 測定では全ての系で, 単 相の X 線回折ピークのみ認められたので, 不純物のない単 相の試料であることを確認した. Table 1 に示すように全て の試料で 1 回目の Li 㨂入では比較的大きな容量が認められ た。とくにモリブデート系は比較的大きな $\mathrm{Li}$ イオン挿入容 量を示した。一方, 放電電位については 12 タングステート ではいずれも Li の電気化学的な挿入に伴う電位は $1.5 \mathrm{~V}$ か ら $0 \mathrm{~V}$ 程度までなだらかに観測された，そこで，平均の電位 をとって, Table 1 中では放電電位として $0.5 \mathrm{~V}$ と標記した。 電位から考えると，この電位は 12 タングステートでは $\mathrm{W}^{6+}$ $/ \mathrm{W}^{5+}$ 及び $\mathrm{W}^{5+} / \mathrm{W}^{4+}$ の還元電位に主に相当して扔り, タング ステン系は正極よりむしろ負極に適した低い電位しか示さな いことがわかった。しかし， $\mathrm{Li}$ の挿入容量は $\mathrm{H}_{4} \mathrm{SiW}_{12} \mathrm{O}_{40}$ で は $460 \mathrm{mAh} / \mathrm{g}$ にも到達し, 比較的大きな容量を示したので, これらのタングステン系へテロポリ酸はむしろ不燃性の負極 活物質として興味ある特性を有することがわかる．これに対 し，モリブデート系では $\mathrm{Mo}^{6+} / \mathrm{Mo}^{5+}$ および $\mathrm{Mo}^{5+} / \mathrm{Mo}^{3+} の$ 還元に対応して，Li のインターカレーションによる電位の 緩やかな低下が $3.0 \mathrm{~V}$ から $1.0 \mathrm{~V}$ まで観察された ${ }^{9,10)}$. 電位 は $1.0 \mathrm{~V}$ 以下でもなだらかに低下したが，正極への念用を考 えて $1 \mathrm{~V}$ でカットオフしたので, 平均電位を求め, $1.5 \mathrm{~V}$ を 放電電位として Table 1 には表した。このように 12 モリブ デートでは比較的電位が高いので, 正極活物質として使用で きる可能性がある. Table 1 に示すようにモリブデン系でも 中心金属が $\mathrm{Si}$ よりも $\mathrm{P}$ の方が $\mathrm{Li}$ の電気化学的な挿入容量は 大きく，中心金属としてはPが適すると考えられる，一方， 後に詳細に議論するが $\mathrm{H}^{+}$型では, 12 個の Mo の 1 個を $\mathrm{V}$ で置換すると抻入容量, 脱離容量ともに大きく向上したので, 周囲の $\mathrm{MoO}_{6}$ ユニットの置換は容量の向上に有効であると 期待できる．これはへテロ原子を導入することで，モリブデ 一ト中の Mo が酸化還元しやすくなることを示唆している. ところで, Table 1 に示したすべてのへテロポリ酸では挿入

Table 1 Electrochemical $\mathrm{Li}$ intercalation in various heterpoly acids.

\begin{tabular}{|c|c|c|c|c|c|}
\hline \multirow[b]{2}{*}{ Sample* } & \multicolumn{2}{|c|}{1 st Cycle } & \multicolumn{2}{|c|}{5 th Cycle } & \multirow[b]{2}{*}{$\begin{array}{c}\text { Discharge } \\
\text { potential** } \\
\text { (V) }\end{array}$} \\
\hline & $\begin{array}{c}\mathrm{Li} \\
\text { de-intercalation } \\
(\mathrm{mAh} / \mathrm{g})\end{array}$ & $\begin{array}{c}\mathrm{Li} \\
\text { intercalation } \\
(\mathrm{mAh} / \mathrm{g})\end{array}$ & $\begin{array}{c}\mathrm{Li} \\
\begin{array}{c}\text { de-intercalation } \\
(\mathrm{mAh} / \mathrm{g})\end{array}\end{array}$ & $\begin{array}{c}\mathrm{Li} \\
\text { intercalation } \\
(\mathrm{mAh} / \mathrm{g})\end{array}$ & \\
\hline $\mathrm{H}_{4} \mathrm{SiW}_{12} \mathrm{O}_{40}$ & 112.2 & 463.6 & 40.2 & 171.9 & 0.4 \\
\hline $\mathrm{H}_{4} \mathrm{PVW}_{11} \mathrm{O}_{40}$ & 82.2 & 380.4 & 26.3 & 92.5 & 0.5 \\
\hline $\mathrm{H}_{3} \mathrm{PMo}_{12} \mathrm{O}_{40}$ & 111.89 & 146.02 & 48.00 & 49.77 & 1.5 \\
\hline $\mathrm{H}_{4} \mathrm{PV}_{1.3} \mathrm{Mo}_{10.7} \mathrm{O}_{40}$ & 213.1 & 298.6 & 114.3 & 192.1 & 1.5 \\
\hline $\mathrm{H}_{4} \mathrm{SiMo}_{12} \mathrm{O}_{40}$ & 97.2 & 110.3 & 64.5 & 73.8 & 1.4 \\
\hline
\end{tabular}


容量は比較的に大きいものの，脱離容量が小さく，繰り返し 特性が悪い。この結果, 5 サイクル後には充放電容量は比較 的小さい値となった.これはこれらのへテロポリ酸は $\mathrm{H}^{+}$型 であり，水溶性なので結晶中に $\mathrm{H}_{2} \mathrm{O}$ を含むとともに, 試料 作成時に水を吸着しやすく, この結晶中の $\mathrm{H}_{2} \mathrm{O}$ が電池中で $\mathrm{Li}_{2} \mathrm{O}$ を生成し, 繰り返し特性の低下を導くものと推定され る。このように，モリブドリン酸が比較的高い放電電位を示 したことから，本研究では縮合へテロポリ酸の中でも 12 モ リブドリン酸に着目して，Li の電気化学的な挿入特性をさ らに詳紐に検討した。

\section{212 モリブドリン酸における電気化学的 Li イオン挿入 の繰り返し特性の向上}

まず，対カチオンのプロトンのアルカリへの置換效果をさ らに検討した. ヘテロポリ酸では 1 分子中に 3 分子のイオン 交換サイトがあり，ここに種々の金属カチオンをイオン交換 できることが知られている，とくに，交換サイトのイオンを $\mathrm{H}^{+}$からアルカリまたはアルカリ土類へイオン交換すること で，難溶性になることが報告されている11)。そこで，本研究 では Table 1 で比較的放電電位が高く, 容量の大きかった市 販の $\mathrm{H}_{3} \mathrm{PMO}_{12} \mathrm{O}_{40}$ に着目して, アルカリイオンとの交換の影 響を検討した. Table 2 には $\mathrm{H}_{3} \mathrm{PMO}_{12} \mathrm{O}_{40}$ におけるアルカリ イオン交換の影響をまとめた. Table 2 に示すようにアルカ リ元素でイオン交換することにより，初回の挿入容量抒よび 脱離容量はともに大きく向上することがわかる．またTable 2 中には 5 サイクル後の容量についても示した. 5 サイクル 後に扔いては容量の低下が依然として認められるものの, $\mathrm{Cs}$ 塩および $\mathrm{Rb}$ 塩では比較的大きな容量が維持されて㧍り， Table 1 に比べるとLiイオンの挿入に対するサイクル特性 が大きく向上することがわかる．とくに，初期の容量および 5サイクル後の容量ともにCsをイオン交換した系において 最も大きな容量が得られた．現在までに充放電サイクルに伴 う容量の低下する機構は不明であるが，アルカリにイオン交 換することで, 12 モリブドリン酸は踈水化するので, 結晶 中の $\mathrm{H}_{2} \mathrm{O}$ が除去され, その結果, $\mathrm{Li}$ の可逆的なインターカ レーションが行われるようになったためと現在のところ推定 している.アルカリイオン交換に伴う容量の増加する機構は, さらに詳細に検討する必要があるが, $\mathrm{Cs}_{3} \mathrm{PMo}_{12} \mathrm{O}_{40}$ が最も良 好な性能を示したので, この系に着目して, さらに詳細な Li イオンの挿入脱離挙動を検討した.

Fig. 2 には Cs 塩の充放電曲線を示した. Li の挿入曲線で は $2.0 〜 1.5 \mathrm{~V}$ に放電電位が現れた。この放電電位は $\mathrm{LiCoO}_{2}$

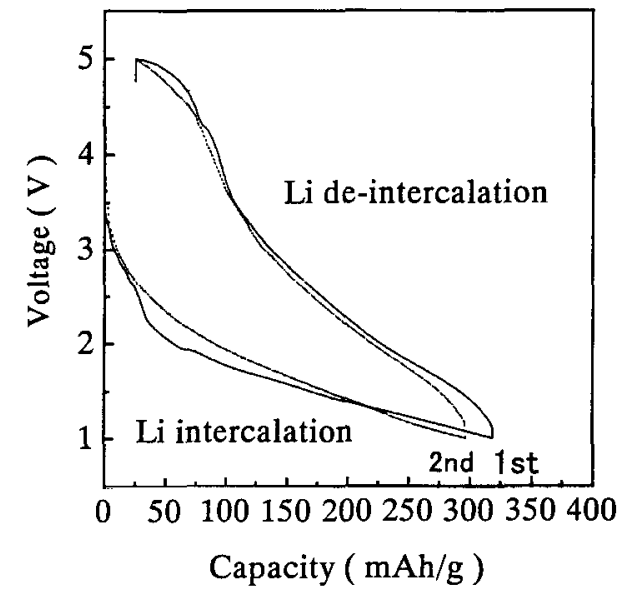

Fig. 2 Charge-discharge profile of $\mathrm{Li}$ intercalation and deintercalation in $\mathrm{CS}_{3} \mathrm{PMO}_{12} \mathrm{O}_{40}$ (Current density: $0.4 \mathrm{~mA} / \mathrm{cm}^{2}$, Potential window: $1.0 \sim 5.0 \mathrm{~V}$ ).

などに比べると低いが，6価の Mo 還元電位にほほ対応した 電位である ${ }^{9,10}$. そこで, $\mathrm{Cs}_{3} \mathrm{PMO}_{12} \mathrm{O}_{40}$ では 6 価の $\mathrm{Mo}$ が酸 化還元しながら Li の挿人・脱離が行われるものと思われる. また, 電気化学的な $\mathrm{Li}$ の脱離は $2.0 \sim 3.0 \mathrm{~V}$ 付近で行われる ことがわかる. Li の挿入と脱離の電位の差が大きいのはこ の $\mathrm{Cs}_{3} \mathrm{PMO}_{12} \mathrm{O}_{40}$ の電気伝導度が低いためであり, 今後, $\mathrm{Cs}_{3} \mathrm{PMO}_{12} \mathrm{O}_{40}$ の微粒子化等により, 伝尊度が向上できるなら ば，各粒子に均一な電流を流すことが可能となるので，放電 電位が平坦になるとともに, 放電と充電の電位差がある程度, 小さくなると期待され，現在検討を行っている.

Fig. 3 には $\mathrm{Cs}_{3} \mathrm{PMo}_{12} \mathrm{O}_{40}$ における $\mathrm{Li}$ の捙入容量の繰り返 し特性を示した. Fig. 3 に示すように放電電位は低いが，容 量は比較的大きく, $300 \mathrm{mAh} / \mathrm{g}$ 以上の初期容量が得られる ことがわかる．一方， $\mathrm{Li}$ の㨂入脱離を繰り返すことで, 容 量は大きく低下したが，5回目以降では容量の低下は顕著で はなくなり，10 サイクル後も $150 \mathrm{mAh} / \mathrm{g}$ と比較的大きな容 量が維持されることがわかる.しかし，充放電の繰り返しに より，抻入容量は次第に低下した。このような充放電サイク ルによる容量の低下する理由としては電解液成分の分解も考 えられるが，Moが酸化還元するにつれて，モリブドリン酸 の結晶構造が徐々に崩壊するためと推定している。

Fig. 4 には $\mathrm{Cs}_{3} \mathrm{PMo}_{12} \mathrm{O}_{40}$ について Li の初期及び 5 回の㨂 人容量の電流密度依存性を示した. 電流密度に依存して導電 凬のアセチレンブラック量の最適值は異なる可能性はあるが,

Table 2 Effects of alkaline cation on the $\mathrm{Li}$ intercalation capacity of 12-molybdophosporic acid.

\begin{tabular}{|c|c|c|c|c|c|}
\hline \multirow[b]{2}{*}{ Sample* } & \multicolumn{2}{|c|}{1 st Cycle } & \multicolumn{2}{|c|}{5 th Cycle } & \multirow[b]{2}{*}{$\begin{array}{c}\text { Discharge } \\
\text { potential** } \\
\text { (V) }\end{array}$} \\
\hline & $\begin{array}{c}\mathrm{Li} \\
\text { de-intercalation } \\
(\mathrm{mAh} / \mathrm{g})\end{array}$ & $\begin{array}{c}\mathbf{L i} \\
\text { intercalation } \\
(\mathrm{mAh} / \mathrm{g})\end{array}$ & $\begin{array}{c}\mathrm{Li} \\
\begin{array}{c}\text { de-intercalation } \\
(\mathrm{mAh} / \mathrm{g})\end{array}\end{array}$ & $\begin{array}{c}\mathrm{Li} \\
\text { intercalation } \\
(\mathrm{mAh} / \mathrm{g})\end{array}$ & \\
\hline $\mathrm{H}_{3} \mathrm{PMO}_{12} \mathrm{O}_{40}$ & 111.89 & 146.02 & 48.00 & 49.77 & 1.5 \\
\hline $\mathrm{K}_{3.0} \mathrm{PMo}_{12} \mathrm{O}_{40}$ & 355.87 & 362.37 & 74.27 & 80.54 & 1.5 \\
\hline $\mathrm{H}_{0.7} \mathrm{Cs}_{2.3} \mathrm{PMO}_{012} \mathrm{O}_{40}$ & 293.66 & 319.33 & 182.16 & 189.30 & 1.5 \\
\hline $\mathrm{H}_{0.4} \mathrm{Rb}_{2.6} \mathrm{PMo}_{12} \mathrm{O}_{40}$ & 297.32 & 330.97 & 155.78 & 156.43 & 1.5 \\
\hline
\end{tabular}

* Chemical formula from ICP and XRF analysis.

* * Discharge potential for Li intercalation.

(Current density: $0.4 \mathrm{~mA} / \mathrm{cm}^{2}$, Potential window: $0.1 \sim 5.0 \mathrm{~V}$.) 


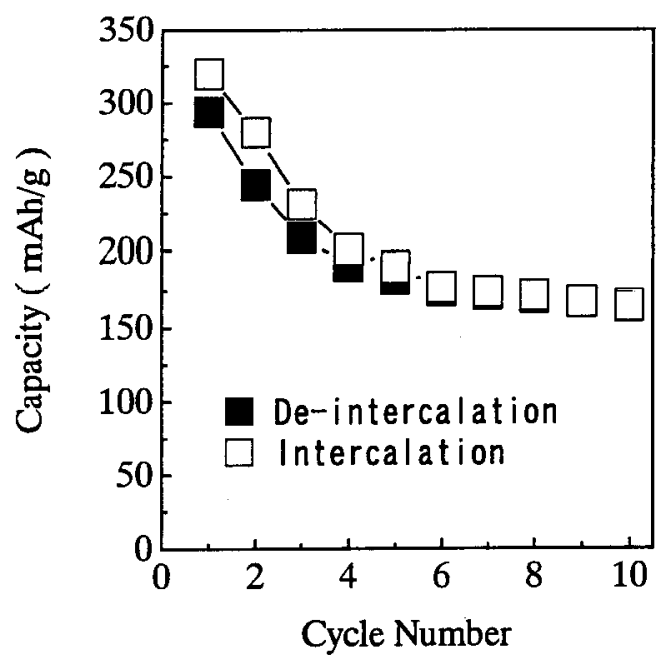

Fig. 3 Cycle stability of Li intercalation and de-intercalation in $\mathrm{Cs}_{3} \mathrm{PMo}_{12} \mathrm{O}_{40}$ (Current density: $0.4 \mathrm{~mA} / \mathrm{cm}^{2}$, Potential window: $1.0 \sim 5.0 \mathrm{~V}$ ).

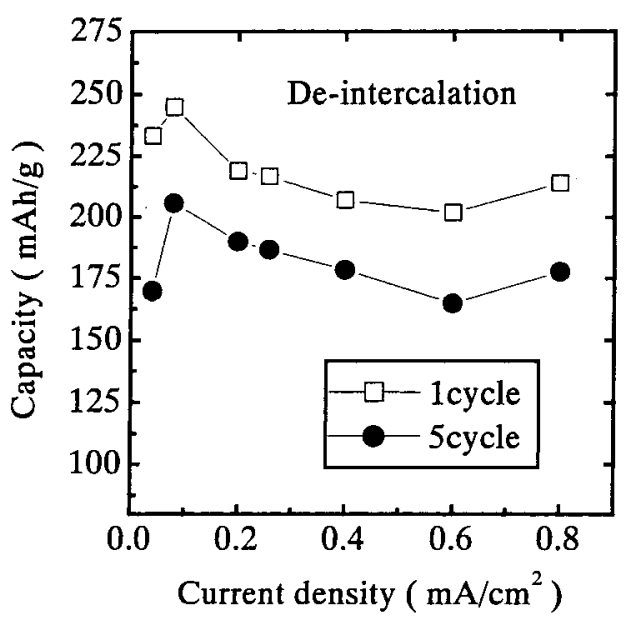

Fig. 4 Effect of current density on the capacity of $\mathrm{Li}$ deintercalation in $\mathrm{Cs}_{3} \mathrm{PMo}_{12} \mathrm{O}_{40}$ (Current density: $0.05 \sim 0.8 \mathrm{~mA}$ / $\mathrm{cm}^{2}$, Potential window: $1.0 \sim 5.0 \mathrm{~V}$ ).

検討したアセチレンブラック添加量 $30 \mathrm{wt} \%$ では, 明らかな ように電流密度が向上しても Li 挿入容量の低下は影著では なく，1 サイクルおよび 5 サイクル後も高電流密度下まで比 較的大きな容量が維持されることがわかった。そこで，Cs を対カチオンとするモリブデートは高電流密度下でも良好な $\mathrm{Li}$ の抻入・脱離が可能であり, 電位は低いながら $1.5 \mathrm{~V}$ 級の 正極材料として応用が期待できる.

次に導電剂としてのアセチレンブラック量が $\mathrm{Cs}_{3} \mathrm{PMO}_{12} \mathrm{O}_{40}$ の Li挿入容量に及ぼす影響を検討した（Fig. 5). $\mathrm{Cs}_{3} \mathrm{PMo}_{12} \mathrm{O}_{40}$ は電気伝導度が低く, 導電剂としてのアセチレ ンブラック量を最適化することで, $\mathrm{Li}$ 挿入容量の増加が期 待される. Fig. 5 に示すように一定量の $\mathrm{Cs}_{3} \mathrm{PMO}_{12} \mathrm{O}_{40}$ に对 する測定では，混合するアセチレンブラック量の増加ととも に $\mathrm{Li}$ 挿入容量は向上し，30〜 $50 \mathrm{wt} \%$ 添加時には初期挿入容 量は約 $350 \mathrm{mAh} / \mathrm{g}$ という比較的良好な容量が得られること がわかった. そこで, アセチレンブラックの添加量としては 30〜50 wt\%が適することがわかる。これはアセチレンブラ ックを添加することで, 試料の伝導度が向上するが, アセチ

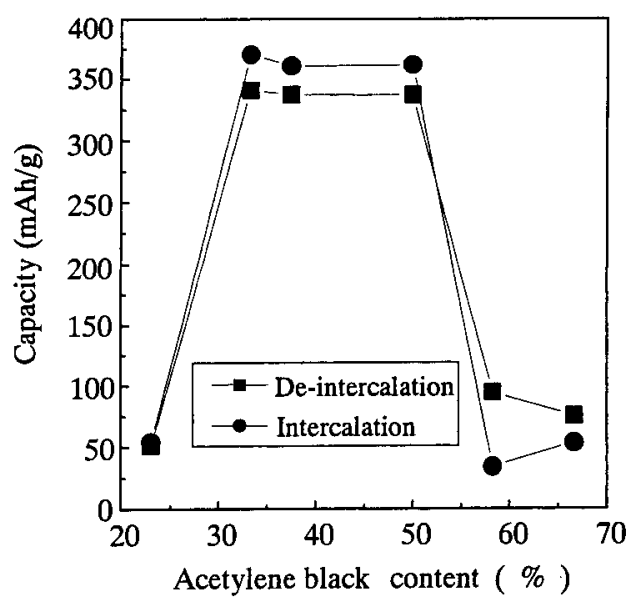

Fig. 5 Effect of acetylene black content on the capacity of $\mathrm{Li}$ intercalation and de-intercalation in $\mathrm{Cs}_{3} \mathrm{PMO}_{12} \mathrm{O}_{40}$ (Current density: $0.4 \mathrm{~mA} / \mathrm{cm}^{2}$, Potential window: $1.0 \sim 5.0 \mathrm{~V}$ ).

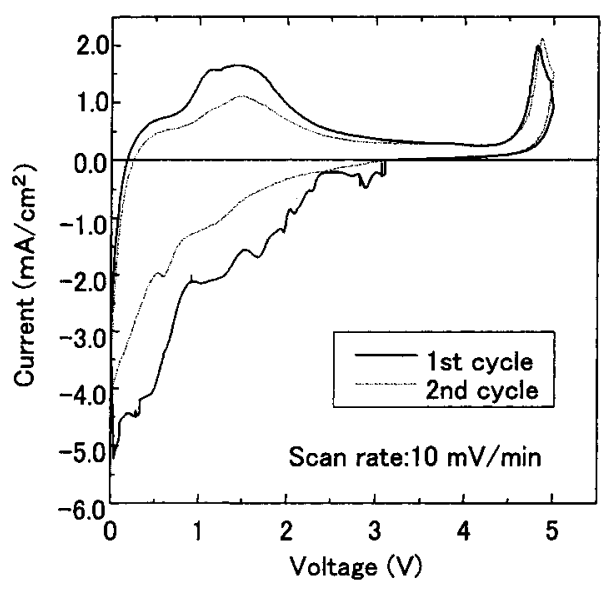

Fig. 6 Cyclic voltammogram curve of $\mathrm{Cs}_{3} \mathrm{PMo}_{2} \mathrm{O}_{40}$ in $1 \mathrm{M}$ $\mathrm{LiPF}_{6}$-EC/DMC. (Scan rate: $10 \mathrm{mV} / \mathrm{min}$, Potential range: $0 \sim$ $5.0 \mathrm{~V})$.

レンブラックが過剰になると $\mathrm{CS}_{3} \mathrm{PMo}_{12} \mathrm{O}_{40}$ 中への $\mathrm{Li}$ の拡散 が十分行われず，容量が逆に低下するものと思われる.

Fig. 6 には $\mathrm{Cs}_{3} \mathrm{PMO}_{12} \mathrm{O}_{40}$ 初期のサイクリックボルタンメト リーの測定結果を示した. 充放電特性に見られるなだらかな 充放電特性から予想されるように1〜2.5Vにわたって，ブ ロードな酸化执よび還元ピークが認められた。そこで, 1.5 $\mathrm{V}$ 付近の放電電位は Moの酸化還元によるものであることは 明らかである。一方，この 12 モリブドリン酸では興味ある

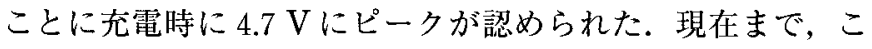
のピークを生じる酸化種については帰属できていないが，こ の酸化ピークに対する還元波は, $3.0 \mathrm{~V}$ 付近から始まる還元 ピークと考えられる. 2 回目以降のサイクリックボルタンメ トリーにもこのピークは認められること，および電解液のみ のサイクリックボルタンメトリーではこの電位にピークがな く, 電解液の分解は $5.3 \mathrm{~V}$ から始まるので,この $4.7 \mathrm{~V}$ は $\mathrm{Cs}_{3} \mathrm{PMo}_{12} \mathrm{O}_{40}$ の酸化ピークであることは明らかである.この $3.0 \mathrm{~V}$ 付近のピーク容量が大きくできるなら 12 モリブドリン 酸は新しい高電位な正極材料として，さらに興味ある材料に なると思われる。

$\mathrm{Cs}$ 塩の Li イオン挿入脱離に伴う結晶構造の変化を検討す るために, 充放電前後の $\mathrm{Cs}_{3} \mathrm{PMO}_{12} \mathrm{O}_{40}$ の XRD 測定を行っ 


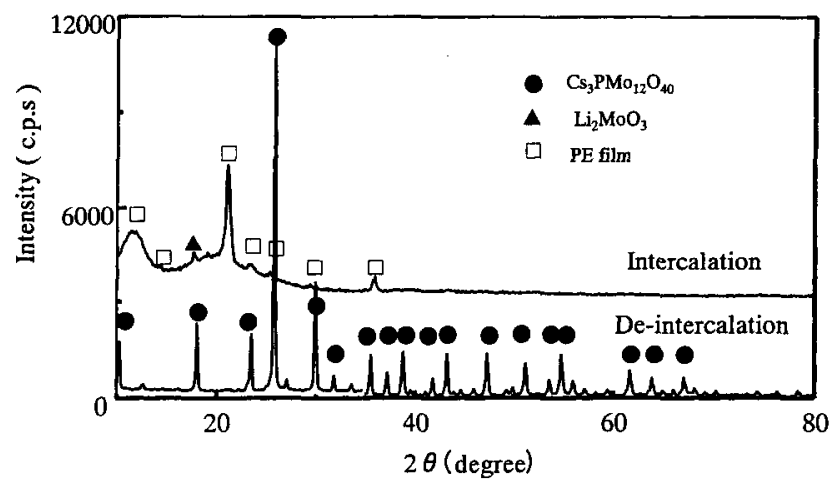

Fig. 7 XRD patterns of $\mathrm{Cs}_{3} \mathrm{PMo}_{12} \mathrm{O}_{40}$ after $\mathrm{Li}$ intercalation and de-intercalation.

た. 3 サイクル目の放電後 (Intercalation と表記) および充 電後 (de-intercalation と表記) の試料をグローブボックス 中でセルから取り出し，ポリエチレンフイルム中に封入して， XRD 測定を行った（Fig.7). Fig.7に明らかなようにLi イ オン挿入後の試料の XRD パターンにはポリエチレンの回折 ピークに加え，強度は弱いながらも $\mathrm{Li}_{2} \mathrm{MoO}_{3} に$ 帰属される 回折ピークが認められる。そこで，Li の充電後には試料は $\mathrm{Li}_{2} \mathrm{MoO}_{3}$ ヘと変化しているものと思われる。一方, Fig. 7 に 示すように 2 サイクル目の充電後に，Liを脱離させると， 再び $\mathrm{Cs}_{3} \mathrm{PMo}_{12} \mathrm{O}_{40}$ に帰属されるへテロモリブデートの高い 強度の XRD パターンが認められたので, ヘテロモリブデー トではMoイオンが 6 価と 5 価，さらに 4 価までを酸化還元 しながら $\mathrm{Li}$ の電気化学的な挿入脱離をしていると思われる. そこで, Moが 4 価と 6 価の間を酸化還元するとすると, 理 論容量は $373 \mathrm{mAh} / \mathrm{g}$ と求まる.これは現在, 検討されてい る多くの正極材料の理論容量と比べても大きな值であり，電 位は低いながらもこの 12 モリブドリン酸が $\mathrm{Li}$ イオン二次電 池の電極活物質として興味ある材料であることを示している. 実際にアセチレンブラック量を最適化して観測された初回の $\mathrm{Li}$ の挿入容量は Fig. 5 に示すように $350 \mathrm{mAh} / \mathrm{g}$ であるので, このモリブデートの初期サイクルの Li イオンの理論挿入量 に対する実際の挿入量の割合は $93 \%$ であり，これは放電深 度として $\mathrm{Li}_{1.86} \mathrm{MoO}_{3}$ に相当する。

さらに容量の向上と放電電位の向上を目的に, $\mathrm{Cs}_{3} \mathrm{PMO}_{12} \mathrm{O}_{40}$ 中の Moの置換を検討した. すでに, Table 1 中で示したように， $\mathrm{H}^{+}$型の 12 モリブドリン酸ではMo 個 Vで置換すると Li の挿入容量が向上することがわかって いる。そこで, Cs 型において Mo の置換効果の検討を行っ た.

\section{3. $3 \mathrm{Cs}_{3} \mathrm{PMo}_{12} \mathrm{O}_{40}$ への異原子置換効果}

12 モリブドリン酸では 1 個以上 Mo を W 及びVなどのカ チオンで置換できることが知られている12,14-16). とくに近年 周辺のMoを数個置換したへテロポリ酸はユニークな酸化還 元挙動を示し, 酸化触媒として興味ある反応を進行できるこ とが報告され注目されている17). そこで，比較的良好な $\mathrm{Li}$ の電気化学的挿入脱離が可能であった $\mathrm{Cs}_{3} \mathrm{PMO}_{12} \mathrm{O}_{40}$ につい てMoの置換効果を検討した. 現在までに, 種々のカチオン を導入したへテロポリ酸の合成を検討した。 その結果， $\mathrm{Nb}$, $\mathrm{W}, \mathrm{V}$ での置換体の合成が可能であった. Table 3 に化学分 析して求めた試料の組成を示した。一方，Fig. 8 には得られ
Table 3 Chemical analysis result of metal substituted $\mathrm{Cs}_{3} \mathrm{PMO}_{12} \mathrm{O}_{40}$.

\begin{tabular}{l|l}
\hline \multicolumn{1}{c|}{ Sample } & \multicolumn{1}{c}{ Analyzed result } \\
\hline $\mathrm{K}_{3} \mathrm{PMo}_{12} \mathrm{O}_{40}$ & $\mathrm{~K}_{3.0} \mathrm{PMo}_{12} \mathrm{O}_{40}$ \\
\hline $\mathrm{Cs}_{3} \mathrm{PMo}_{12} \mathrm{O}_{40}$ & $\mathrm{H}_{0.7} \mathrm{Cs}_{2.3} \mathrm{PMo}_{12} \mathrm{O}_{40}$ \\
\hline $\mathrm{Rb}_{3} \mathrm{PMo}_{22} \mathrm{O}_{40}$ & $\mathrm{H}_{0.4} \mathrm{Rb}_{2.6} \mathrm{PMo}_{12} \mathrm{O}_{40}$ \\
\hline $\mathrm{Cs}_{4} \mathrm{PVMo}_{11} \mathrm{O}_{40}$ & $\mathrm{H}_{1.0} \mathrm{Cs}_{3.0} \mathrm{PV}_{1.3} \mathrm{Mo}_{10.7} \mathrm{O}_{40}$ \\
\hline $\mathrm{Cs}_{3} \mathrm{PWMo}_{11} \mathrm{O}_{40}$ & $\mathrm{H}_{0.2} \mathrm{Cs}_{2.8} \mathrm{PW}_{1.0} \mathrm{Mo}_{11.0} \mathrm{O}_{40}$ \\
\hline $\mathrm{Cs}_{4} \mathrm{PNbMo}_{11} \mathrm{O}_{40}$ & $\mathrm{H}_{1.8} \mathrm{Cs}_{2.2} \mathrm{PNb}_{1.2} \mathrm{Mo}_{10.8} \mathrm{O}_{40}$ \\
\hline
\end{tabular}

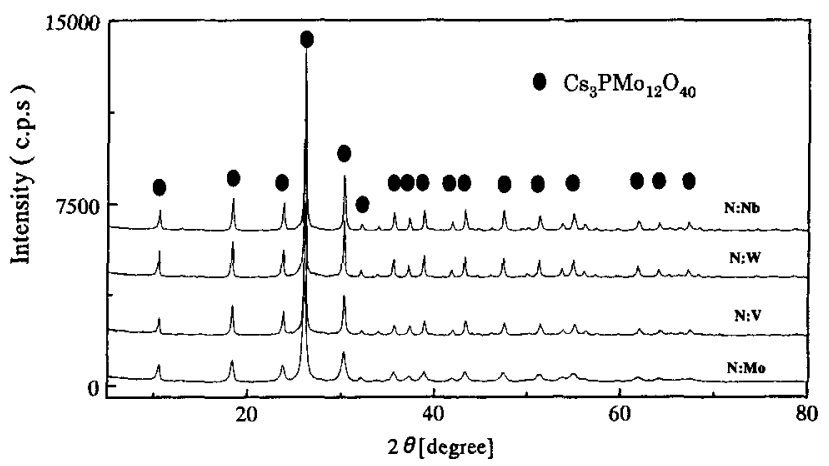

Fig. 8 XRD pattern of various metal ions substituted to $\mathrm{Cs}_{3} \mathrm{PMO}_{12} \mathrm{O}_{40}$.

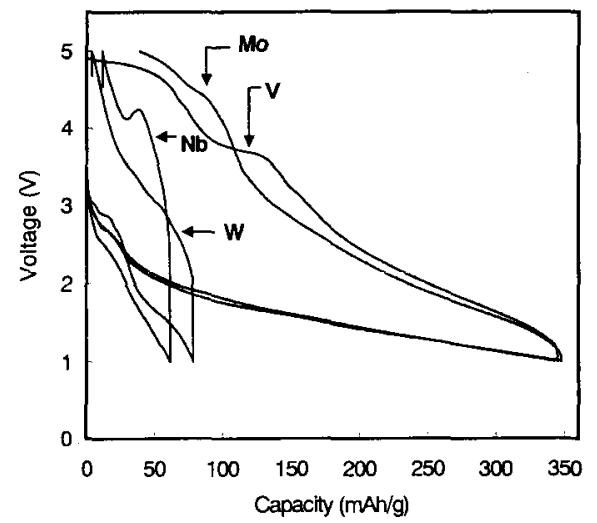

Fig. 9 Charge-discharge curves for $\mathrm{Li}$ intercalation in $\mathrm{Cs}_{3} \mathrm{PXMo}_{11} \mathrm{O}_{40}$ type (X: Mo, V, W, Nb) (Current density: 0.4 $\mathrm{mA} / \mathrm{cm}^{2}$, Potential window: $1.0 \sim 5.0 \mathrm{~V}$ ).

た置換体のXRD パターンを示した。明らかなようにいずれ の系も 12 モリブドリン酸のXRD パターンを示し, Table 3 に表すようにICPによる組成分析から，ほぼMo 1 個が久 損し，代わりに Nb，W．またはV Vが含有されているので, $\mathrm{Nb} ， \mathrm{~W}$ ，またはV Vでの置換が行われたことがわかる。

Fig. 9 には，V，W 又は $\mathrm{Nb}$ 部分置換としたへテロポリ 酸の充放電特性を示した。明らかなように $\mathrm{Nb}$ 及びWを導 入すると $\mathrm{Li} の$ 挿入容量は大きく減少した，これは $\mathrm{Nb}$ 又は Wの導入により格子が不安定になったためと考えられる.

一方，V導入すると， $\mathrm{H}^{+}$型の場合と同様に $\mathrm{Cs}^{+}$型に打い ても大きな容量が得られることがわかった。またVを置換 することで脱離曲線の $4 \mathrm{~V}$ 付近にVの 4 価, 5 価の酸化に起 因すると思われる電位の平端部が新たに出現した。 そこで Mo を V で置換することは充放電電位の向上に有効であると 考えられる．以上のように，格子中への異原子の添加につい ては充放電電位の向上から有効であり，Moを置換する元素 
を選択することで, さらに, 高い放電電位での $\mathrm{Li}$ の電気化 学的な挿入, 脱離が可能になる可能性が示唆される.Moの 部分置換效果については現在, さらに詳細な検討を行ってお り，結果については今後報告する尒定である。

\section{4 結 論}

本研究で 12 モリブドリン酸抢よび 12 タングストリン酸に おける Li イオンの電気化学的な挿入, 脱離を検討し, 以下 のことを明らかにした。

1. $\mathrm{H}_{3} \mathrm{PMo}_{12} \mathrm{O}_{40}$ は $1.5 \mathrm{~V}$ の放電電位と比較的大きな容量を有 寸るので, Li イオン電池の正極としての応用が期待され る.一方, $\mathrm{H}_{4} \mathrm{PVW}_{11} \mathrm{O}_{40}$ などのタングステートは $0.5 \mathrm{~V}$ 程度の電位を有するので, むしろ負極材料としての応用 の可能性がある。

2. $\mathrm{H}_{3} \mathrm{PMO}_{12} \mathrm{O}_{40}$ では交換するイオンにより, 容量および繰 り返し特性が向上し, $\mathrm{Cs}_{3} \mathrm{PMo}_{12} \mathrm{O}_{40}$ は $1.5 \mathrm{~V}$ と電位は低 いながら約 $300 \mathrm{mAh} / \mathrm{g}$ という大きな可逆容量を有する ことがわかった。

3. $\mathrm{Cs}_{3} \mathrm{PMo}_{12} \mathrm{O}_{40}$ では 10 サイクル後も $170 \mathrm{mAh} / \mathrm{g}$ 程度の比 較的大きな容量を有し, $0.8 \mathrm{~mA} / \mathrm{cm}^{2}$ という比較的大き な電流密度でも大きな容量が維持されることがわかった。

4. XRD 测定から Mo は 6 価から 4 価までを酸化還元しなが ら Li の電気化学的な挿入, 脱離が行われており, 理論挿 入容量は $373 \mathrm{mAh} / \mathrm{g}$ となることがわかった. 実際に最 適化された条件での $\mathrm{Cs}_{3} \mathrm{PMo}_{12} \mathrm{O}_{40}$ への $\mathrm{Li}$ の電気化学的 な挿入容量は $350 \mathrm{mAh} / \mathrm{g}$ であり, 挿入効率は約 $93 \%$ で あった。

5. $\mathrm{Mo}$ を 1 原子 $\mathrm{V}$ で置換した $\mathrm{Cs}_{3} \mathrm{PMO}_{12} \mathrm{O}_{40}$ では $4 \mathrm{~V}$ 付近に $\mathrm{V}$ の酸化が起因する放電電位が新たに出現した。 そこで, 添加元素老選択することで, $\mathrm{Cs}_{3} \mathrm{PMo}_{12} \mathrm{O}_{40}$ 中の $\mathrm{Mo}$ の酸 化・還元挙動を変化させ, 放電電位をさらに, 向上でき る可能性があると推定される.

\section{文 献}

1) M. Yoshio and A. Ozawa, Lithium Ion Niji Den-chi, Zairyo to Oyou, Nikkan Kogyo Shuppan, Tokyo, Chap. 3, p. 36 (2000) (in Japanese).

2) C. Delmas, J. P. Peres, A. Rongier, A. Demourgues, F. Weill, A. Chadwicc, M. Broussely, F. Perton, P. Biensan, and P. Willmann, J. Power Sources, 68, 120 (1997).

3) J. R. Dahn, U. V. Sacken, M. R. Jukow, and H. Al-Janaby, J. Electrochem. Soc., 138, 2207 (1991).

4) V. Maner, B. Banov, A. Momchiler, and A. Nassalevska, J. Power Sources, 57, 99 (1995).

5) A. K. Padhi, K. S. Nanjundaswamy, and J. B. Goodenough, J. Electrochem. Soc., 144, 1188 (1997).

6) M. S. Wittingham, J. Electrochem. Soc., 123, 315 (1976).

7) M. Martos, J. Morales, and L. Sanchez, Electrochim. Acta, 46, $83(2000)$.

8) A. Manthiram and J. Kim, Chem. Mater., 10, 2895 (1998).

9) G. Guzman, B. Yebka, J. Livage, and C. Julien, Solid State Ionics, 86-88, 407 (1996).

10) Y. Uebou, S. Okada, and J. Yamaki, 69th Annual Meeting of the Electrochemical Society of Japan, Abstr., p.222, (2002) (in Japanese).

11) M. Shibata, Kagaku to Kogyo, 11, 322(1958) (in Japanese).

12) M. T. Pope, Heteropoly and Isopoly Oxometalates, Springer-Verlag, p.78 (1983).

13) Y. Xia, Y. Zhou, and M. Yoshio, J. Electrochem. Soc., 144, 2593 (1997).

14) F. Kern, S. Ruf, and G. Emig, Applied Catalysis A. General, 150, 143 (1997).

15) G.A. Tsigdinos and C.J. Hallada, Inorg. Chem., 7, 437 (1968).

16) J. Peng, Y. Zhou, E. Wang, Y. Xing, and H.Q. Jin, J. Molecular Structure., 444, 213 (1998).

17) J.S. Min and N. Mizuno, Catal. Today, 71, 89 (2001). 